Journal of Engineering and Applied Sciences 14 (Special Issue 7): 10018-10022, 2019

ISSN: 1816-949X

(C) Medwell Journals, 2019

\title{
Water Quality Assessment of Rivers and Heavy Metal Analysis of Small Scale Black Pepper Farm in Singai Area, Bau
}

\author{
Sharifah Nadzirah Binti Wan Hamid, Bellona Joseph, Mathressa Mathews and \\ Shirley Shireano Anak Karl \\ School of Chemistry and Enviromental Studies, Faculty of Applied Science, \\ Universiti Teknologi MARA Sarawak, 94300 Kota Samarahan, Sarawak, Malaysia
}

\begin{abstract}
Agriculture is one of the most important economic activities and it is essential to sustain livehood. However, this agriculture activities give big impacts to the environmental as it use pesticide, insecticide and fertilizer that contain heavy metals and affecting the water quality. In Bau Singai, the farming of pepper is still one of the sources of the villagers for income generation. Thus, fertilizer is one of the necessity for the plant growth where the villager will use a few types of fertilizer. The heavy metals content in the fertilizers, black pepper plant and river in the villagers were determined. The samples of fertilizer and black pepper were taken from 4 differents places of villages which are Kampung Sudoh, Kampung Apar, Kampung Bobak and Kampung Atas whereas the water sample were taken from Kampung Atas, Kampung Daun and Kampung Bobak. The concentration of heavy metals was analyzed by using Atomic Absorption Spectroscopy (AAS) using wet digestion method for fertilizers, black pepper and water samples. The water quality parameters tested via. In-situ were $\mathrm{pH}$, temperature, turbidity and Dissolved Oxygen (DO) and Total Dissolved Solids (TDS). While for ex-situ measurements were Biochemical Oxygen Demand (BOD), Chemical Oxygen Demand (COD), Total Suspended Solids (TSS), Phosphorus reactive $\left(\mathrm{PO}_{4}^{3-}\right)$, Nitrate $\left(\mathrm{NO}_{3}\right.$ ) and ammoniacal nitrogen $\left(\mathrm{NH}_{3} \mathrm{~N}\right)$. The estimated intake of $\mathrm{Ni}, \mathrm{Cu}, \mathrm{Fe}$ and $\mathrm{Cd}$ from black pepper were within the WHO tolerable intake. The Water Quality Index (WQI) at Kampung Atas is 80 with status of slightly polluted (Class II), Kampung Daun is 86 with status of clean (Class II) and Kampung Bobak is 78 with status of slightly polluted (Class II). For black pepper and fertilizer the concentration is within WHO tolerable intake. As for heavy metals in water, $\mathrm{Pb}$ have exceed the permissible limit in river at Kampung Atas.
\end{abstract}

Key words: Heavy metal, black pepper, water quality assessment, parameters, Total Dissolved Solids (TDS), permissible limit

\section{INTRODUCTION}

This study was conducted in river areas at Singai, Bau which is located in Sarawak (Fernandez, 2016). It is known that river is one of the larger contributions for natural stream of water sources which flowing into several places into the reservoir, dam and other water resources. At Singai, most of the villagers planted black pepper nearby their houses as apart for their food sources or financial purposes. Clean water supply is needed in order to avoid plants being harmed by the quality of the water (Sumok, 2001). Even though there are some lack of information, it is important to access water quality of the rivers (Chang et al., 2001). There are many human activities that contribute to pollution, such throwing rubbish and rearing animals such as chicken, duck, cows and other activities. Since, water is important for many usages, the possibility of water pollution can happen and affect both villager's usage and black pepper growth
(FAO, 2010). Having a good quality of water is essential to avoid the villagers from any diseases and pollutions from the usage of fertilizer and pesticide. The main chemical of phosphates lead to entroplication that lead to unpleasant taste and odour of the water when alga decomposed, thus deteriorating the quality of the water. The high concentration of phosphate after rainy season is due to leaching of phosphate fertilizer. The objectives for this study are to investigate the water quality of river at Kampung Atas, Kampung Daun and Kampung Bobak, Bau based on the parameters (temperature, Biological Oxygen Demand (BOD), pH, Chemical Oxygen Demand (COD), nitrate, ammoniacal nitrogen, Dissolved Oxygen (DO), phosphorus reactive, Total Dissolved Solids (TDS), Total Suspended Solids (TSS) and turbidity. To classify rivers at Singai, Bau areas are based on Malaysia Interim National Water Quality Standards (INWQS) guidelines. The second objective is to identify the concentration of selected heavy metals such Copper (Cu), Nickel (Ni), lead

Corresponding Author: Sharifah Nadzirah Binti Wan Hamid, School of Chemistry and Enviromental Studies, Faculty of Applied Science, Universiti Teknologi MARA Sarawak, 94300 Kota Samarahan, Sarawak, Malaysia 
$(\mathrm{Pb})$ and iron $(\mathrm{Fe})$ in rivers at Kampung Atas, Kampung Daun and Kampung Bobak by using Atomic Absorption Spectroscopy (AAS) to compare the metals with the standard permissible limit from World Health Organization (WHO). The findings point to a potential health threat posed by heavy metal pollution to human and other forms of life in the aquatic ecosystems.

\section{MATERIALS AND METHODS}

Sample preparation: From the Singai area, five main villages were randomly chosen as locations of interest to obtain black pepper and fertilizer samples. The samples were transferred into plastic zipper-lock bags, sealed and labelled accordingly. Water samples were taken directly in the rivers at Kampung Atas, Kampung Daun and Kampung Bobak then were preserved by nitric acid in water solutions at concentrations of $0.15 \%$ by weight or at $\mathrm{pH}$ range between 1.62 or greater (USEPA., 2012). Then the water samples were kept in the chiller also to preserve the water samples from being contaminate. Standard methods from APHA (1999) was used on sample preservation and analytical procedures.

Aqua regia digestion: After the samples were weighed, $9 \mathrm{~mL}$ of concentrated hydrochloric acid and $3 \mathrm{~mL}$ of concentrated nitric acid were added into each conical flask. The flasks were gently swirled. The solution in the conical flasks was heated on a hot plate in a fume chamber for $1 \mathrm{~h}$ at $100^{\circ} \mathrm{C}$. The temperature was reduced if the solution started to boil. The filtered solution was diluted with deionised water up to the calibration mark. Blank and control samples were obtained using the same procedures.

Atomic absorption spectrometry: Standard of 1-5 ppm were prepared using $100 \mathrm{~mL}$ volumetric flask. About 1-5 mL were pipetted out from the $100 \mathrm{ppm}$ universal standard. The standards were put into five separate $100 \mathrm{~mL}$ volumetric flasks, respectively and marked up to calibration mark. The Atomic Absorption Spectrophotometer (AAS) was calibrated using the prepared standard solution. Calibration curve was plotted with the absorbance of the standard against the concentration of standard. After calibration of AAS, samples were analysed by using auto-sampler. Results obtained were tabulated and calculated.

In-situ analysis: Additionally, in situ data measurement usually will measure $\mathrm{pH}$, temperature, turbidity, Dissolved Oxygen (DO). These types of parameter usually measured as it relate to water pollution. Parameters such as $\mathrm{DO}, \mathrm{pH}$, temperature and total dissolved solids were checked directly by using YSI Water Checker Model 650 MDS whereby turbidity was checked by using turbidity meter. The results were recorded directly at the site where the water samples were taken at each of the points.

\section{Ex-situ analysis}

Biological Oxygen Demand (BOD): The method started with water samples filled into three BOD bottles. YSI Water Checker Model 650 MDS is used to measure the DO level. Next, aluminium foil used to wrap the BOD bottles then left for incubation for five days in a dark room. After left for incubation, the estimation of the BOD were measured by analyzed done on the residual oxygen (USEPA., 2012).

Chemical Oxygen Demand (COD): Water samples were measured by using Hach kit (method code with Hach 8000 method). Right after it switched to thermo reactor, the preheating process done by setting the temperature at $148^{\circ} \mathrm{C}$. Then a Hach COD reagent cell was filled with $2.0 \mathrm{~mL}$ deionized water (blank sample) using a $1000 \mu \mathrm{L}$ micropipette and the cap closed the cell firmly analyzed according to manual.

Total suspended solids: TSS of the water samples were analyzed by using APHA (1999) method.

Phosphorus reactive, nitrate and ammoniacal nitrogen: The labelled water samples were analyzed using ascorbic acid reduction method (3653-SC) for phosphorus reactive, cadmium reduction method (3649-SC) for nitrate analysis and Nesslerization method code (3642-SC) for ammoniacal nitrogen. All of the methods were done according to LaMotte smart Colorimeter manual.

\section{RESULTS AND DISCUSSION}

Black pepper heavy metal analysis: The results revealed wide variation in heavy metal content in five (5) different black pepper samples collected from Singai area, Bau.

Figure 1 demonstrated the concentration of lead at five different villages. The results indicated that black pepper samples obtained from Kampung Senibung has the highest concentration of lead. The content of lead was found to be at $0.3009 \mathrm{mg} / \mathrm{kg}$.

Figure 2 indicated that black pepper samples obtained from Kampung Senibung has the highest concentration of nickel. The content of nickel was found to be at $0.0470 \mathrm{mg} / \mathrm{kg}$.

Figure 3 demonstrated that black pepper samples obtained from Kampung Bobak has the highest 


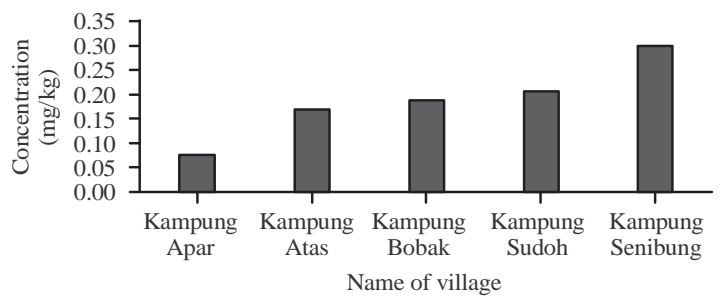

Fig. 1: The average concentration of lead in black pepper (pb)

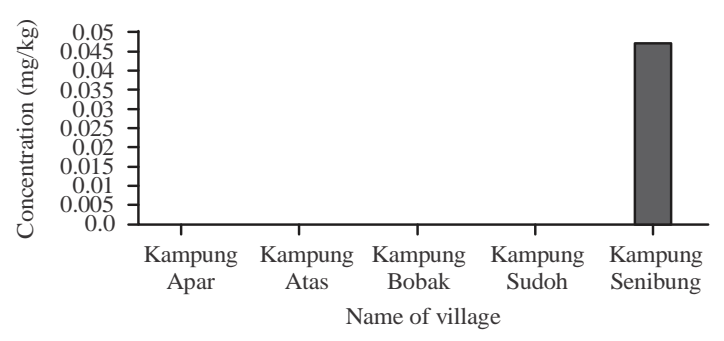

Fig. 2: The average concentration of Nikel in black pepper (Ni)

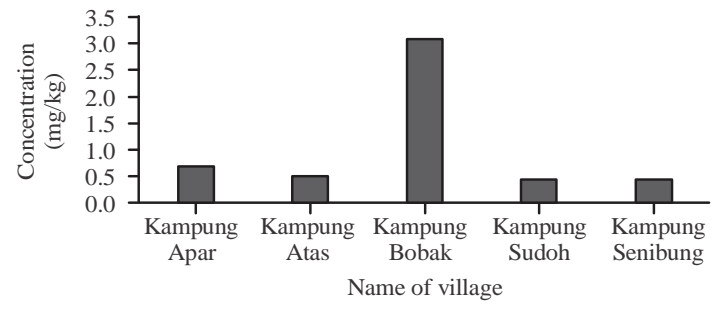

Fig. 3: The average concentration of copper in black pepper $(\mathrm{Cu})$

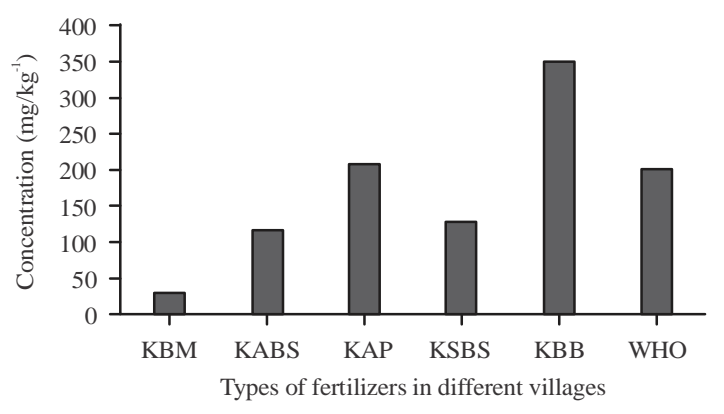

Fig. 4: The average concentration of copper in black pepper (Fertilizer)

concentration of copper at $3.0970 \mathrm{mg} / \mathrm{kg}$. The concentration $\mathrm{Ni}, \mathrm{Cu}$ and $\mathrm{Pb}$ from black pepper were within the WHO (2004) tolerable intake.

Fertilizer heavy metal analysis: From Fig. 4, the highest KBB concentration of copper in this sample is $0.6997 \mathrm{ppm}$ or $349.85 \mathrm{mgkg}^{-1}$ which

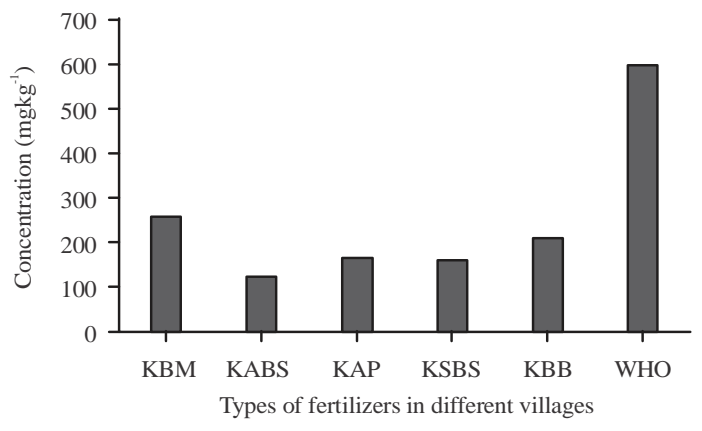

Fig. 5: The average concentration of lead in black pepper (Fertilizer)

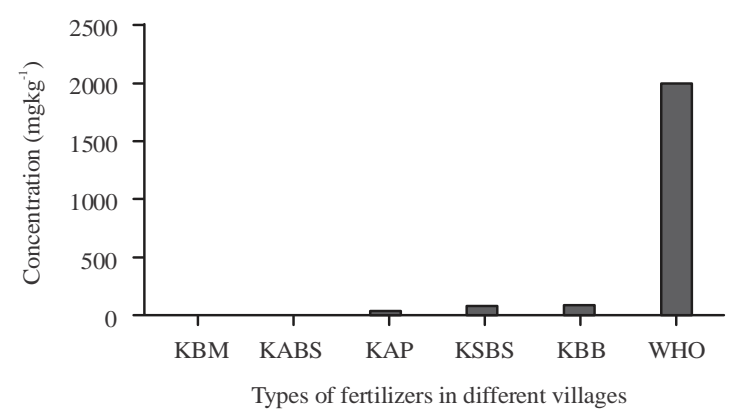

Fig. 6: The average concentration of nickel in black pepper (Fertilizer)

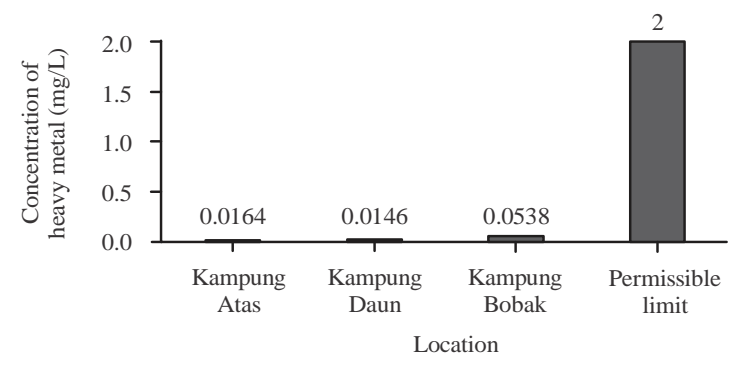

Fig. 7: The average concentration copper in rivers at Kampung Atas, Kampung Daun and Kampung Bobak (Cu)

Table 1: The samples location and labelling

\begin{tabular}{ll}
\hline Locations & Labellings \\
\hline Kampung Bobak Mixer & KBM \\
Kampung Atas & KABS \\
Kampung Apar & KAP \\
Kampung Sudoh & KSBS \\
Kampung Bobak Blue & KBB \\
\hline
\end{tabular}

exceeds the permissible limits. Any adverse impact of the fertilizer on soil characteristics may lead to ultimate loss of soil fertility in near future (Table 1).

Figure 5 and 6 shown the concentration of lead and nickel in fertilizer sample were WHO $(2000,2004)$ permissible limit (Fig. 7). 
J. Eng. Applied Sci., 14 (Special Issue 7): 10018-10022, 2019

Table 2: Mean values of parameter in rivers at Kampung Atas, Kampung Daun and Kampung Bobak

\begin{tabular}{llll}
\hline Parameters & Kampung Atas & Kampung Daun & Kampung Bobak \\
\hline pH & 7.99 & 7.40 & 6.90 \\
Temperature $\left({ }^{\circ} \mathrm{C}\right)$ & 27.83 & 26.51 & 25.59 \\
Turbidity $(\mathrm{NTU})$ & 4.91 & 3.76 & 5.335 \\
Biochemical oxygen demand (mg/L) & 0.013 & 0.018 & 0.01 \\
Chemical oxygen demand (mg/L) & 13.42 & 10.83 & 21.91 \\
Dissolved oxygen (\%) & 40.75 & 60.7 & 40.43 \\
Total Dissolved Solid (TDS) & 0.0704 & 0.0535 & 0.02 \\
Total suspended solid & 0.0010111 & 0.0018667 & 0.0056500 \\
Phosphorus reactive (mg/L) & 0.2144 & 0.00722 & 0.161 \\
Nitrate $(m g / L)$ & 0.487 & 0.389 & 0.375 \\
Ammoniacal nitrogen (mg/L) & 0.098 & 0.191 & 0.222 \\
Water Quality Index (WQI) & 80 & 86 & 78 \\
Status & Slightly polluted & Clean & Slightly polluted \\
Categories & Class II & Class II & Class II \\
\hline
\end{tabular}

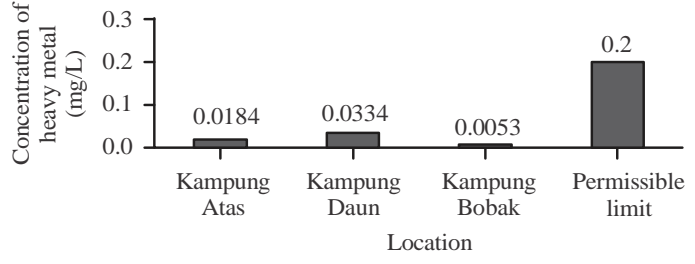

Fig. 8: The average concentration nikel in rivers at Kampung Atas, Kampung Daun and Kampung Bobak (Ni)

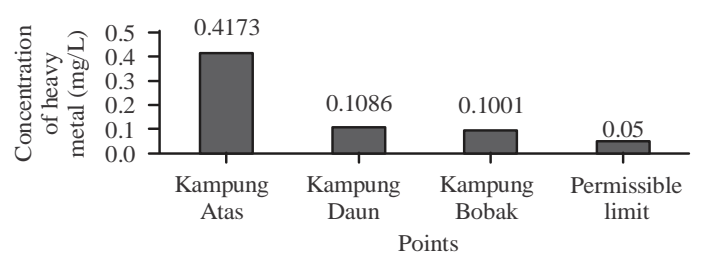

Fig. 9: The average concentration lead in rivers at Kampung Atas, Kampung Daun and Kampung Bobak $(\mathrm{Pb})$

Analysis of heavy metals in water sample: According to Fig. 7, water samples concentration of copper ranged between $0.0146-0.0538 \mathrm{mg} / \mathrm{L}$ are below the permissible limit. The permissible limit for $\mathrm{Cu}$ in water is $2 \mathrm{mg} / \mathrm{L}$ (Nazir et al., 2015). Kampung Bobak has the highest concentration of $\mathrm{Cu} 0.0538 \mathrm{mg} / \mathrm{L}$.

Water samples concentration of nickel shown in Fig. 8 ranged between $0.0053-0.0334 \mathrm{mg} / \mathrm{L}$ shown as below the permissible limit. The maximum permissible limit for $\mathrm{Ni}$ in the water is $0.2 \mathrm{mg} / \mathrm{L}$ (Nazir et al., 2015). Kampung Daun (0.0334 mg/L) shown the highest concentration of nickel among other two points (Fig. 9).

According to WHO standards permissible limit of lead in water is $0.05 \mathrm{mg} / \mathrm{L}$. Concentration of lead in all the collected water samples ranged between 0.1001-0.4173 mg/L which exceed the permissible limit of WHO standards. Kampung Atas has $0.4173 \mathrm{mg} / \mathrm{L}$ shown the highest concentration of lead and exceed the permissible limit. The observation that link high $\mathrm{Pb}$ concentration at Kampung Atas was mainly because of littering packaging product are mostly chemicals that are used to add up color. Packaging, dye substances and ink pigments and chemical manufacturing industries always use heavy metals such as $\mathrm{Pb}$.

Water quality analysis: Based on Table 2, from three rivers shown that rivers at Kampung Atas and Kampung Bobak classified as slightly polluted and Kampung Daun are stated as clean. These class II water can be used after conventional treatment required and sensitive towards aquatic species. Any recreational use with body contact can be permitted with class II water bodies. Furthermore, the ground water pollution may only be noticed when the water is consumed and negative impacts becomes obvious. Therefore, a regular water quality assessment is necessary to detect early signs of water pollution. The water pollution may only be noticed when the water is consumed and negative impacts becomes obvious. Therefore, a regular water quality assessment is necessary to detect early signs of water pollution.

\section{CONCLUSION}

The heavy metal content in black pepper in all sample location was within the WHO tolerable intake. The heavy metal content concentration of copper in the fertilizer from Kampung Bobak is exceeds the WHO permissible limits. On behalf of the heavy metals concentration in the river, lead content in Kampung Atas is above the permissible limit but other concentration of heavy metal are in range of the permissible limit. To conclude, three points of rivers at Bau, Kuching which are Kampung Atas, Kampung Daun and Kampung Bobak were taken for water quality assessment together with heavy metals analysis. The results obtained for Water 
Quality Index (WQI) at Kampung Atas is 80 with status of slightly polluted (Class II), Kampung Daun is 86 with status of clean (Class II) and Kampung Bobak is 78 with status of slightly polluted (Class II). These results showed the impact of small scale agriculture activities towards river quality through non-point sources from the villager's farm.

\section{ACKNOWLEDGEMENTS}

First and foremost, I would like to declare my gratitude to the almighty Allah as I managed to complete this research by his praise, guidance and blessings. This research is supported byte hard work, dedication and consistency of Bellona, Mathressa and Shirley during their final year project. I would like to thank the villagers of Singai, Bau for their hospitality and welcoming gesture during our visit for the study.

\section{REFERENCES}

APHA., 1999. Standard methods for the examination of water and wastewater. American Public Health Association, Washington, USA. http://dl.icdst.org/pdfs/files/9b8d1f12b54f3154c8c6 48e0ec810185.pdf

Chang, N.B., H.W. Chen and S.K. Ning, 2001. Identification of river water quality using the fuzzy synthetic evaluation approach. J. Environ. Manage., 63: 293-305.
FAO, 2010. Food and Agriculture Organization. Food and Agriculture Organization of the United Nations, Rome, Italy.

Fernandez, K., 2016. A place in Malaysia you've probably never heard of: Bau, Sarawak. ExpatGo, Malaysia. https://www.expatgo.com/my/ 2016/04/01/place-malaysia-youve-probably-neverheard-bau-sarawak/

Nazir, R., M. Khan, M. Masab, Hameed ur Rehman and Naveed Ur Rauf et al., 2015. Accumulation of heavy metals $(\mathrm{Ni}, \mathrm{Cu}, \mathrm{Cd}, \mathrm{Cr}, \mathrm{Pb}, \mathrm{Zn}, \mathrm{Fe})$ in the soil, water and plants and analysis of physico-chemical parameters of soil and water collected from Tanda Dam kohat. J. Pharm. Sci. Res., 7: 89-97.

Sumok, P., 2001. River water quality monitoring: sharing Sarawak experience. Proceedings of the 6th SITE Research Seminar, September 13-14, 2001, SITE Research, Kota Kinabalu, Malaysia,-pp: 1.

USEPA., 2012. Water: Monitoring and assessment. United States Environmental Protection, Washington, D.C., USA. https://www.epa.ie/water/wm/

WHO., 2000. Air Quality Guidelines. 2nd Edn., WHO Regional Office for Europe, Copenhagen, Denmark, ISBN:9289013583, Pages: 288.

WHO., 2004. Trace elements in human nutrition and health. World Health Organization, Geneva, Switzerland. 